\title{
Factors Affecting Student's Academic Performance in Ahuntegen General Secondary School, North Wollo Zone, Ethiopia
}

\author{
Birhan Getachew \\ Department of Geography and Environmental Studies, Debre Tabor University, Ethiopia
}

\begin{abstract}
Article Info
Article history:

Received Dec 21, 2017

Revised Feb 19, 2018

Accepted Apr 21, 2018

\section{Keywords:}

Academic

Performance

Chi-Square test

Multiple Regressions

ABSTRACT

The Academic performance of the student depends on a number of factors such as teachers, student and school related variables. Hence, this study was conducted to analyze the factors which affect the academic performance of students. Primary and secondary data were used for the study. In this paper, students' results were taken from record office. Multiple regressions, chisquare test, correlation analysis were used to analyze the data. The result of the chi-square test and correlation analysis portrayed that teachers educational level, experience, subject matter knowledge, students interest towards education, attendance, parents educational level, parents income, distance of the school from the students home, the availability of materials, text book and language skill of students have an influence for the academic success of students. Besides, keeping other variables constant, $14.8 \%$ and $62.7 \%$ variability of students' academic performance was explained by teacher and school related variables whereas the overall $74.2 \%$ of variations of students' results were explained by 19 variables applied for this study. The overall relationship was statistically significant $(\mathrm{F} 19,23=8.592, \mathrm{P}<0.001)$. It is recommended that analyzing and understanding of teachers, students, parents, school educational expert and related variables are very essential to improve the academic performance of students.
\end{abstract}

Copyright () 2018 Institute of Advanced Engineering and Science. All rights reserved.

\section{Corresponding Author:}

Birhan Getachew,

Department of Geography and Environmental Studies,

Debre Tabor University,

P.O. Box 272, Debre Tabor, Ethiopia.

Email: birhangetachew2@gmal.com

\section{INTRODUCTION}

Countries throughout the world have made a lot of efforts to expand education with in their country as they know development can't be achieved without education. But the effort varies from countries to countries. Developed countries like Germany, Britain and France have given first task for education. As a result, they become economically and politically powerful. The same is true in Northern America and Canada since the secret of their technological advance in any filed is the result of education. Giving priority for modern education further go to Asia, Japan, South Korea, China, India and others who become the new tiger of the economy as they give especial attention for education [4].

Wagaw stated that [13] African countries take a lesson from the above mentioned countries and started to give priority for education. Since 1940 Countries like Republic of South Africa (RSA), Egypt, Nigeria, China, Morocco, Tunisia and others have brought remarkable change with their economic development. Even though there were civil war and other political instabilities have existed in many parts of African countries have tried to educate their nations. However, countries in which their nations have not got the chance of education due to political unrest and civil war remain without economic progress. We can take South Sudan and Somalia is good examples. 
Negash [8] in his study described that Ethiopia has given attention for modern education since 1940 on words that the country has started expanding education from Addis Ababa to different parts of the country. However, due to financial, political, technical problems modern education cannot be expanded as it was planned. But, the Dreg government tried to expand modern education but the number of colleges and universities were limited. In addition, the civil war in the country created an obstacle for the foundation of colleges and universities.

Since 1992 the government of Ethiopia was started the explanation of education institutions by allowing the participation of the private sectors in the field of education. As a result, many primary, secondary and tertiary educations have been opened. The government has established a lot of colleges and universities at different parts of the country and many people have got the chance of attending college and university education. The government opened universities in different parts of Ethiopia. As are result, thousands of students have graduated and employed in private and government organizations [12]. However, many graduates in these days can't get the chance of employment. Even though, Ethiopia have made a lot of efforts to expand primary, secondary and tertiary education, the quality of education has got a serious challenge since many students before and after graduation can't cope up the necessary knowledge for the level. To tackle the problem the government has made efforts [15].

Tefera [11] also found that Ethiopia is a developing country of East Africa. Like other developing country one the main reasons for its' underdevelopment is the low quality of education which has in turn great impact on the country's Social, economic and political system. Quality of education is of great concern for stakeholders in education including politicians, educators, teachers, parents, students and the Ethiopian community at large. The declining performances of students at both primary and secondary school levels in external examinations have necessitated a series of workshops for secondary school teachers. Several studies have shown that Ethiopia's educational expansion is plagued by the prevalence of poor quality across the education sectors from primary to higher education.

According to Saeed [10] low quality education, especially in developing countries, is linked with a number of factors related to school, head teacher, teacher, parent and community. Various factors affect student achievement at secondary level like personal confidence and a feeling of competence in learning; hopeful but realist projection into the future occupational roles and social roles; emotional stability; temperamental tendency towards introversion; relative independence from teacher and a tacit acceptance of the curricular and work demands arising within the structure of tuition [13]. Achievement is affected by students' personal characteristics, attitude, activities and most of all students' interest and engagement. Students with low academic self-esteem and the students that are not interested and activity engaged are at a significantly higher risk of low achievement [7].

Along with these factors pertaining to the students personalities, family background is also very important. Research indicates that students from lower socio-economic background in terms of parents' occupational status faced a higher risk of low achievement. Home educational background and parents educational attainment greatly influences the quality of education for their children. Student achievement was found to be directly proportional to the education of their parents [6]. Guidance services provided by the institute play a significant role in achievement. Guidance services have services have significantly positive effect on students study attitudes, study habits and academic achievement [3]

Identifying factors that influence students learning and thus achievement continues to be an important objective of educators at all levels [2]. Even though, the government has a made a paramount effort to expand number of schools, college and universities as well as the enrollment of students at varies stages, the quality of education were remained under question since the inception of modern education still now. Hence, those students who were passed from one grade level to other grade level as well as those students who graduate from government and private universities and colleges did not acquire the necessary knowledge, skills and attitudes. Despite these facts, efforts were not made to know the root cause of these problems. As a result, this research was designed to analyze the factors that affect students' achievement at secondary education level.

\section{RESEARCH METHOD}

The main purpose of the study was to find out the factors that affect students' achievement. The dependent variable (i.e student achievement) was measured by achievement test that was given at school level in 2005 E.C. the independent variable that refers to factors which affect student achievement in this study included school condition/environment, teachers related variables, school, management, school structure and supply, language of instruction, students' background and community options. The following tables show their relationship and descriptions 
Table 1. Description of Variables

\begin{tabular}{|c|c|c|}
\hline & Variables & Descriptions \\
\hline $\begin{array}{l}\text { Dependent } \\
\text { variable }\end{array}$ & Students Achievement & Grade 9 exam results in 2005 E.C \\
\hline \multirow{6}{*}{$\begin{array}{l}\text { Independent } \\
\text { variables }\end{array}$} & Students home background & Students' interest, attendance, sex \\
\hline & Socio-economic factors & Educational materials, parents education and occupation \\
\hline & School structure and resources & $\begin{array}{l}\text { Location, class size, provision of instruction materials text book, } \\
\text { availability and use of pedagogical center, lab, library }\end{array}$ \\
\hline & Teacher related variables & Teachers qualification; years of experience and knowledge of subject matter \\
\hline & School management & School director and supervisor qualification, organization \\
\hline & Parents/community participation & $\begin{array}{l}\text { Parents involvement to solve school problems, their attitude towards } \\
\text { education, teachers and students }\end{array}$ \\
\hline
\end{tabular}

\subsection{METHODOLOGY}

This study is designed as descriptive that assesses the factors which affect the academic performance of students. Therefore, to accomplish the proposed research with respect to the objectives and the nature of the research questions of the study, both qualitative and quantitative data collection and analytical techniques were employed. In the quantitative aspect, grade 92005 e.c academic results were employed. A qualitative technique was used to analyze data collected through interview. Furthermore, qualitative approaches were used in conjunction with quantitative approaches to strengthen quantitative data.

\subsection{Sampling Techniques}

In order to get reliable data 2013 grade 10 registered students were selected as a target population. There are 48 grade 10 students. Out of this 20 students were females and 28 were males. These 48 students were used as a sampling frame. After getting the total population size; the next step was selecting an appropriate sample size. A number of factors include the purpose of the study population size and the precision, the level of confidence or rise and the degree of variability in the attribute being reassured inferences determination of an appropriate sample size. The level of the sample error is 0.05 at $95 \%$ of confidence level and 0.5 is taken as a maximum availability of the population are assumed. Several formulas can be used to get the appropriate sample size. However, Yamane [16] provides a simplified formula to calculate sample sizes.

$$
\mathrm{n}=\frac{N}{1+N(e 2)} .
$$

Where $\mathrm{n}=$ sample size, $\mathrm{N}=$ total students (i.e 250) $\mathrm{e}=$ Sampling error (i.e. 0.05) and $1=$ constant number. Then, substituting 48 for $(\mathrm{N})$ value and 0.05 for $\left(\mathrm{e}^{2}\right)$ the final sample size for this study was 43 . For qualitative data, one teacher from each department was selected and contacted to focus group discussion. Besides, PTA (Parent Teacher Association) members, EB (Education Board) members, coordinators of education quality assurance and educational experts at woreda level were participating in the individual indepth interview.

\subsection{Data Collection Techniques}

Primary and secondary data source were used in this study, primary data was collected through questionnaire and interview. Secondary data was collected from library sources magazines, record office and other documentary sources and researches were also used.

\subsection{Data Analysis}

The Statistical Package for Social Science (SPSS) version 20 windows was used for analyzing the data collected during the questionnaire survey. Each question in the questionnaires was identified by a variable name and within variables; there were values labels for identification of responses from the respondents. After coding the information from the questionnaire, entering data in the computer was carried out. The coded data was then entered in the SPSS computer program where frequencies, Chi-square test, correlation, mean, standard deviations and multiple regressions were computed during the analysis.

\subsection{Variables Specification and Working Hypothesis}

Here an attempt was made to analyze the relationship between students' academic performance and different independent variables or explanatory variables that are expected to influence the academic performance of the students. Accordingly, there are 19 independent variables assumed to influence their academic performance. 
$\mathrm{Y}=\mathrm{b}_{1}+\mathrm{b}_{2} \mathrm{TEL}+\mathrm{b}_{3} \mathrm{TWL}+\mathrm{b}_{4} \mathrm{TTE}+\mathrm{b}_{5} \mathrm{TSK}+\mathrm{b}_{6} \mathrm{SLI}+\mathrm{b}_{7} \mathrm{SS}+\mathrm{b}_{8} \mathrm{AS}+\mathrm{b}_{9} \mathrm{SLD}+\mathrm{b}_{10} \mathrm{DS}+\mathrm{b}_{11} \mathrm{TSR}+\mathrm{b}_{12} \mathrm{FI}+\mathrm{b}_{13} \mathrm{FEL}+\mathrm{b}_{14} \mathrm{SEMS}$ $+\mathrm{b}_{15} \mathrm{SPLLU}+\mathrm{b}_{16} \mathrm{DSEL}+\mathrm{b}_{17} \mathrm{SOM}+\mathrm{b}_{18} \mathrm{CI}+\mathrm{b}_{19} \mathrm{CA}+\mathrm{b}_{20} \mathrm{SGC}+\mathrm{U}$

Where, $\mathrm{Y}$ is the dependent variable and it represents academic performance of the students and $\mathrm{b} 1, \mathrm{~b} 2, \mathrm{~b} 3 \ldots$ and $\mathrm{b} 20$ are the coefficients. $\mathrm{U}$ represents the disturbance term of the model.

The exogenous variables of the model are:

a. TEL: Teachers Education Level. It represents the current educational level of teachers. It shows the qualification of teachers in terms of diploma, degree and above. When the educational level of teachers increased, his ability to teach the study also increased.

b. TWL: Teachers Work Load. It refers to the maximum amount of class that the teacher will teach. If he teaches different grade level as well as maximum period per week, he feels weakness and unable to teach all classes as well as grade level at uniform performance.

c. TTE: Teachers Teaching Experience. This refers to the total year of experience of the teacher in teaching.

d. TSK: Teachers Subject matter Knowledge. This refers to the knowledge of the teacher related to the subject matter he/she taught.

e. SLI: Students Learning Interest. This refers to the interest of students to learn or attained education.

f. SS: Sex of Students. The biological characteristic of students.

g. AS: Attendance of the students. It represents in how many classes, students attained in last academic year.

h. SLD: Students Language Difficulties: this refers to the language problems of the students that they have faced during the learning process.

i. DS: Distance of Schools from the students' house.

j. TSR: Teacher Student Ration. The ratio between teacher and students.

k. FI: Family Income. The family can provide better facilities to the student if the family income is high.

1. FEL: Families Education level. This refers to the educational level of his her parents.

m. SEMS: Schools Educational Materials Supplies. This refers to the availability of the educational materials.

n. SPLLS: Schools Pedagogical center availability, Library and Laboratory Supplies. This refers to the availability of different teaching aids in the pedagogical center, availability of different text books, different laboratory equipment.

o. DSEL: Director and Supervisors Educational Level. This refers to the educational level of directors, supervisors.

p. SOM: School Organization and Management. This is the general technical organization and management of the school which puts influence on the academic performance of students.

q. CI: Community Involvement. This refers to the involvement of the communities to solve educational by supporting the necessary educational materials.

r. CA: Community Attitude towards teachers and students. Community attitude towards teachers and students can influence the academic performance of students.

s. SGC: School Guidance and Counseling. This refers to the school guidance and Counseling that is the applicability of this service.

\subsection{Expected Relation of Independent Variables}

Operational definitions of all variables were described in the above section. Here expected relations of independent variables with dependent variables were described. In this case, the presence or absence of all these variables may have positive or negative influence on the academic achievement of students. Therefore, the presence of better teacher educational level, minimum work load, high teaching experience and subject matter knowledge, high learning interest, being male, continuously attending classes, high language proficiency, nearness of the school in the students home, better teacher-student ration, highest family income and educational level, availability of sufficient educational materials, presence of well-equipped pedagogical center, better educational level of director and supervisors, presence of well-organized school, schools supported by active community participation and the availability of school guidance and counseling may have positive influence on the academic achievement of students otherwise the revise were true.

\section{RESULTS AND DISCUSSION}

\subsection{Analysis of the Relationship between Students Result with Different Variables}

Analysis of students' academic achievement with their families' education level, sex and rate of attending classes continuously were computed. The cross tabulation were made in order to see the relationship with their academic achievement. Accordingly, those students who scored better results were coming from educated families whereas students coming from illiterate families were scored minimum passing marks and below passing marks. This is because those students who come from educated families 
have got a better chance to fulfill the necessary educational facilities that are very essential to be used as an educational input.

The relationship between academic performance of student with their sex also proof that those students who scored better results were male. This is due to male students most focused on their education after schooling hours whereas female students were ordered to execute different home tasks and therefore did not get time to read and prepare themselves. On the other hand, those students who did not miss their classes were scored better result than other students who missed their classes always.

In addition to the above three variables, analysis of student result with respect to students interest towards education, availability of educational materials, distance of school from their home and their attitude towards education were computed.

Table 2 ( $\mathrm{a}, \mathrm{b}, \mathrm{c}$ and $\mathrm{d}$ ) indicates the relationship between these variables with academic achievement. Accordingly, those students who scored highest points had high interest to attained education, have gotten different educational materials, their schools were established near to their place of residences and put high value about the importance of education.

To clearly detect the relationship, chi-square were carried out. The analysis of chi-square test at $5 \%$ significant level $\left(\mathrm{x}^{2}=45.361, \mathrm{P}<0.05, \mathrm{x}^{2}=56.640, \mathrm{P}<0.05, \mathrm{X}^{2}=36.373, \mathrm{P}<0.05\right.$ and $\left.\mathrm{X}^{2}=30.049, \mathrm{P}<0.05\right)$ portrayed that there were strong relationship between students result with students interest towards education, availability of educational materials, distance of school from their home and their attitude towards education respectively. For instance Raychaudhuri (2010) stated that material inputs that are directly linked to the instructional processes consistently influence pupils' achievement. Many scholars hold that school's learning achievement is a function of the material inputs expended per pupil and the efficiency with which these inputs are managed by the teachers and the headmaster.

Table 2. Relationship between Students' Result with (a) Degree of Interest towards Education, (b) Availability of Educational Materials, (c) Place of Residency and (d) Attitude of Students towards Education Respectively

\begin{tabular}{ccccccccccc}
\hline \multirow{2}{*}{ Result } & \multicolumn{9}{c}{ Degree of Interest to Towards Education (a) } & \multicolumn{2}{c}{ Total } & $X^{2}$ & P-value \\
& Very High & High & Medium & Low & Very Low & No & & & \\
\hline $50 \%$ & - & - & 2 & 8 & 3 & 3 & 16 & 45.361 & 0.034 \\
$51-55 \%$ & - & - & 1 & 5 & 3 & - & 9 & & \\
$56-70 \%$ & 1 & 1 & 5 & 2 & 1 & - & 10 & \\
$71-85 \%$ & 3 & 2 & - & - & - & - & 5 & & \\
Above $86 \%$ & 3 & - & - & - & - & - & 3 & & \\
Total & 7 & 3 & 7 & 15 & 7 & 3 & 43 & & \\
\hline
\end{tabular}

\begin{tabular}{cccccc}
\hline \multirow{2}{*}{ Result } & $\begin{array}{c}\text { Availability of Educational Materials (b) } \\
\text { Nos }\end{array}$ & No & Total & \multirow{2}{*}{$X^{2}$} & \multirow{2}{*}{ P-value } \\
\hline $50 \%$ & 3 & 13 & 16 & 56.640 & 0.045 \\
$51-55 \%$ & 1 & 8 & 9 & & \\
$56-70 \%$ & 7 & 3 & 10 & \\
$71-85 \%$ & 5 & - & 5 & \\
Above $86 \%$ & 3 & - & 3 & \\
Total & 19 & 24 & 43 & & \\
\hline
\end{tabular}

\begin{tabular}{|c|c|c|c|c|c|}
\hline \multirow{2}{*}{ Result } & \multicolumn{2}{|c|}{ Place of residency (c) } & \multirow{2}{*}{ Total } & \multirow{2}{*}{$\mathrm{X}^{2}$} & \multirow{2}{*}{ P-value } \\
\hline & Urban & Rural & & & \\
\hline $50 \%$ & 3 & 13 & 16 & 36.373 & 0.037 \\
\hline $51-55 \%$ & 3 & 6 & 9 & & \\
\hline $56-70 \%$ & 8 & 2 & 10 & & \\
\hline $71-85 \%$ & 4 & 1 & 5 & & \\
\hline Above $86 \%$ & 2 & 1 & 3 & & \\
\hline Total & 21 & 23 & 43 & & \\
\hline
\end{tabular}

\begin{tabular}{|c|c|c|c|c|c|c|c|c|}
\hline \multirow[b]{2}{*}{ Result } & \multicolumn{5}{|c|}{ Attitude of students towards education (d) } & \multirow[b]{2}{*}{ Total } & \multirow[b]{2}{*}{$X^{2}$} & \multirow[b]{2}{*}{ P-value } \\
\hline & $\begin{array}{c}\text { Most } \\
\text { interested }\end{array}$ & $\begin{array}{c}\text { Very } \\
\text { interested }\end{array}$ & interested & $\begin{array}{c}\text { Not } \\
\text { interested }\end{array}$ & Dislikes & & & \\
\hline $50 \%$ & - & - & 5 & 4 & 7 & 16 & 30.049 & 0.378 \\
\hline $51-55 \%$ & 1 & 2 & 1 & 3 & 2 & 9 & & \\
\hline $56-70 \%$ & 4 & 5 & 1 & - & - & 10 & & \\
\hline $71-85 \%$ & 4 & 1 & - & - & - & 5 & & \\
\hline Above $86 \%$ & 3 & - & - & - & - & 3 & & \\
\hline Total & 12 & 8 & 7 & 7 & 9 & 43 & & \\
\hline
\end{tabular}




\subsection{Summary of Descriptive Statistics}

The analysis of this statistics shows the mean, median, minimum, maximum and the standard deviation of the students' exam results. The mean score of the students is 54.05 , while the median score of the students result is 55 . Thus, 55 median score is greater than the mean score of the students indicates that students who scored 55 and above results are greater than $50 \%$ of the sampled students. This means that higher result scoring students are greater in number than lower result scoring students. The standard deviation of the students result was 13.156 whereas the minimum and maximum score of students result were 50 and 86 respectively.

Table 3. Summary of Descriptive Statistics

\begin{tabular}{llllll}
\hline $\mathrm{N}$ & Mean & Median & Std.Deviation & Minimum & Maximum \\
\hline 43 & 54.05 & 55 & 13.156 & 50 & 86 \\
\hline
\end{tabular}

\subsection{Regression Model}

\subsubsection{Variables Related to Students, Teachers and Schools and Academic Achievement}

Table 4. (a) shows the correlation between students' academic achievement and other variables that are expected to affect their achievement. Accordingly, all variables used for this investigation shown positive as well as significant relationship at $1 \%$ probability level. From the variables that were used for this investigation, students' interest towards education and students' attendance in the school were found to have significant positive relationship with the academic performance of students.

Table 4. (b) shows the correlation between variables related to teachers and students academic performance. All variables correlated with students result and relationships were statistically significant at $1 \%$ and 5\% probability level. On the other hand, among school structure and management variables, distance of the school from their place of residence, student teacher ratio, students' family income level, school material supply, pedagogical center, community involvement, families home language and families educational level shown positive and significant relationship whereas educational level of director and supervisor, guidance and counseling, school organization and management and community attitude variables shown positive but statistically insignificant

Table 4. Correlation between (a) Student Related variables, (b) Teacher Related Variables and (c) School Related Variables with Academic Achievement Respectively

\begin{tabular}{ccc}
\hline Variables (a) & Pearson correlation & One tailed significance \\
\hline Students interest & $0.62^{* *}$ & 0.003 \\
Absenteeism & $0.56^{*}$ & 0.019 \\
\hline
\end{tabular}

\begin{tabular}{lll}
\hline Variables (b) & Pearson correlation & One tailed significance \\
\hline Teacher Educational Level & $0.563^{*}$ & 0.052 \\
Teacher Work Load & $0.636^{* *}$ & 0.000 \\
Teaching experience & $0.948^{* *}$ & 0.000 \\
Teachers subject matter knowledge & $0.72^{* *}$ & 0.000 \\
\hline
\end{tabular}

\begin{tabular}{lll}
\hline Variables (c) & Pearson correlation & One tailed significance \\
\hline School Structure and Management & & \\
Distance from school & $0.94^{* *}$ & 0.004 \\
Student teacher ratio & $0.54^{*}$ & 0.006 \\
Students family income & $0.56^{*}$ & 0.019 \\
School materials supply & $0.669^{* *}$ & 0.000 \\
Pedagogical center & $0.83^{* *}$ & 0.000 \\
Education level of director & 0.301 & 0.067 \\
School organization and management & 0.244 & 0.076 \\
Availability of guidance & 0.326 & 0.033 \\
Community involvement & $0.557^{*}$ & 0.032 \\
Community attitude & 0.302 & 0.657 \\
Families home language & $0.83^{* *}$ & 0.000 \\
Families educational level & $0.67^{*}$ & 0.034 \\
\hline
\end{tabular}

** Correlation is significant at 0.01 levels (one tailed)

* Correlation is significant at 0.05 levels (one tailed) 


\subsection{Prediction Model}

Table 5 shows prediction of each variables influence on the academic performance of students. It was found from table 5 that standardized coefficient of percentage of students learning interest and attendance were 0.124 and 0.109 and t-value of 0.782 and 0.684 were significant at $95 \%$ and $99 \%$ confidence interval. It implies that impact of students learning interest, being male and students attendance on his/ her academic performance were positive and it shows that if there is 1perecnt increase in students learning interest the academic performance of students will be increased by $78.2 \%$ and $68.4 \%$ respectively.

On the other hand, it is found from the table 5 that standardized coefficient of percentage of teacher educational level, teachers work load, teacher teaching experience and teacher subject matter knowledge were $0.105,-0.017,0.249$ and 0.231 and $t$ value of $0.650,-0.108,1.497$ and 1.436 were significant at 955 and $99 \%$ confidence interval. It implies that impact of teacher's educational level, teachers teaching experience and teachers' subject matter knowledge on the academic performance of student is positive and shows that if there is 1 percent increase in teachers' educational level, teachers teaching experience and teacher subject matter knowledge, the academic performance of students will increase by $65 \%, 149.7 \%$ and $143.6 \%$. On the other hand, teachers work load and academic performance of students is negative. The result also proved that if there is 1 percent increase in teacher work load will decrease by 10.8 percent respectively.

The academic performances of students were also predicated related to school related variables. Therefore, it is believed that different school related variables were expected to have positive and negative impacts on students' academic achievement. To this effect, the standardized coefficient of percentage of distance of the school from students home, student teacher ratio, students family income, school materials supply, pedagogical center, educational level of director and supervisor, school organization and management, availability of guidance, community involvement, community attitude, families home language and families education level were $-0.413,0.501,0.057,0.057,0.040,0.256,0.154,0.500,0.118,0.283,0.115$ and 0.008 and $t$ value were also $-0.171,0.509,0.342,0.343,0.306,2.082,0.029,0.582,0.752,1.816,0.865$ and 0.057 which were statistically significant. These implies that if there is 1 percent increase in student teacher ratio, students family income, school materials supply, pedagogical center, educational level of director and supervisor, school organization and management, availability of guidance, community involvement, community attitude, families home language and families education level, the academic performance of students will be increased by 50\%, 34.2\%, 34\%, 30.6\%, 20\%, $2.9 \%, 58 \%, 75.2 \%, 18 \%, 86 \%$ and $5.7 \%$ respectively.

Table 5. Multiple Regression Model based on Variables Related to Student, Teacher and School

\begin{tabular}{|c|c|c|c|c|c|}
\hline \multirow{2}{*}{ Model } & \multicolumn{2}{|c|}{ Unstandardized coefficient } & \multirow{2}{*}{$\begin{array}{c}\text { Standardized } \\
\text { coefficient } \\
\text { Beta } \\
\end{array}$} & \multirow[t]{2}{*}{$\mathrm{t}$} & \multirow{2}{*}{ Significance } \\
\hline & $\mathrm{B}$ & SE & & & \\
\hline \multicolumn{6}{|c|}{ Student related variables } \\
\hline Constant & 48.503 & 6.688 & & 7.252 & 0.000 \\
\hline SLI & 1.004 & 1.284 & 0.124 & 0.782 & 0.045 \\
\hline AS & 1.087 & 1.589 & 0.109 & 0.684 & 0.035 \\
\hline \multicolumn{6}{|c|}{ Teacher Related variables } \\
\hline Constant & 45.538 & 6.754 & & 6.742 & 0.000 \\
\hline TEL & 1.049 & 1.614 & 0.105 & 0.650 & 0.020 \\
\hline TWL & 0.163 & 1.503 & -0.017 & -0.108 & 0.014 \\
\hline TTE & 02.984 & 1.993 & 0.249 & 1.497 & 0.043 \\
\hline TSK & 2.406 & 1.675 & 0.231 & 1.436 & 0.052 \\
\hline \multicolumn{6}{|c|}{ School related Variables } \\
\hline Constant & 54.134 & 6.463 & & 8.375 & 0.000 \\
\hline DS & 3.966 & 1.251 & -0.413 & -0.171 & 0.003 \\
\hline TSR & 4.439 & 1.265 & 0.501 & 0.509 & 0.001 \\
\hline FI & 0.785 & 2.293 & 0.057 & 0.342 & 0.35 \\
\hline SEMS & 0.770 & 2.243 & 0.057 & 0.343 & 0.034 \\
\hline SPLLS & 0.390 & 1.273 & 0.040 & 0.306 & 0.041 \\
\hline DSEL & 2.500 & 1.200 & 0.256 & 2.082 & 0.046 \\
\hline SOM & 1.600 & 1.555 & 0.154 & 0.029 & 0.012 \\
\hline SGC & 5.692 & 1.589 & 0.500 & 0.582 & 0.001 \\
\hline CI & 1.419 & 1.886 & 0.118 & 0.752 & 0.033 \\
\hline $\mathrm{CA}$ & 4.000 & 2.203 & 0.283 & 1.816 & 0.043 \\
\hline SLD & 1.123 & 1.298 & 0.115 & 0.865 & 0.052 \\
\hline FEL & 0.092 & 1.623 & 0.008 & 0.057 & 0.055 \\
\hline
\end{tabular}

\subsection{Summary of Multiple Regression Model}

Table 6 shows summary of multiple regression models. To this end, overall, multiple regression analysis based on students', teachers and school related variables resulted in a model which was able to 
explain $2.8 \%, 14.8 \%$ and $62.7 \%$ of the variation of the academic performance of students respectively.

Table 6. Multiple Regression Model Summary Based on Variables Related to Students, Teachers and School Structure and Management.

\begin{tabular}{ccccc}
\hline Model & $\mathrm{R}$ & $\mathrm{R}$-square & Adjusted R-Square & Std. Error of the estimate \\
\hline Student Related variables & 0.166 & 0.028 & 0.022 & 13.463 \\
Teacher Related variables & 0.384 & 0.148 & 0.058 & 12.770 \\
School Related variables & 0.792 & 0.627 & 0.478 & 9.510 \\
\hline
\end{tabular}

\subsection{Multiple Regression Analysis Models' Summary by Using Hierarchical Linear Model}

The variables selected to predict the academic achievement of students were derived from the questionnaire. The variables derived from the students' response were only those which give sense when aggregated to school level. The predictors were organized into blocks and initially each block was analyzed separately in order to explore its contribution to the final model as shown in Table 7.

Table 8 . shows the hierarchical regression models summary which indicates the $\mathrm{R}^{2}$ change when one block is added to the other. The number of variables in each model is indicated under the first column and the change statistics shows the $\mathrm{R}^{2}$ change gained when one block is added to the other to build the final model. Table 8 below shows that the regression was a fair fit $\left(\mathrm{R}^{2}=74.2 \%\right)$ and the overall relationship was statistically significant $\left(\mathrm{F}_{19}, 23=8.592, \mathrm{P}<0.001\right)$. The model is the best model because there is no significance difference between the $\mathrm{R}$ square value and adjusted $\mathrm{R}$ square.

Table 7. Multiple Regression Results Organized by Separate Blocks of Variables

\begin{tabular}{|c|c|c|c|c|c|c|}
\hline S.No & Variables name & $\begin{array}{c}\text { Stand. } \\
\text { Coefficient }\end{array}$ & $\mathrm{R}^{2}$ & Adj. $R^{2}$ & $\mathrm{~F}$ & $\mathrm{df}$ \\
\hline & Student Related Variables & & 0.028 & 0.022 & 0.370 & 3 \\
\hline 1 & Students interest & 0.124 & & & & \\
\hline 2 & Absenteeism & -0.109 & & & & \\
\hline & Teacher Related Variables & & 0.148 & 0.058 & 1.646 & 4 \\
\hline 1 & Teacher Educational Level & 0.105 & & & & \\
\hline 2 & Teacher Work Load & -0.017 & & & & \\
\hline 3 & Teaching experience & 0.249 & & & & \\
\hline 4 & Teachers subject matter knowledge & 0.231 & & & & \\
\hline & School Related Variables & & 0.627 & 0.478 & 2.401 & 12 \\
\hline 1 & Distance from school & -0.413 & & & & \\
\hline 2 & Student teacher ratio & 0.501 & & & & \\
\hline 3 & Students family income & 0.057 & & & & \\
\hline 4 & School materials supply & 0.057 & & & & \\
\hline 5 & Pedagogical center & 0.040 & & & & \\
\hline 6 & Education level of director & 0.256 & & & & \\
\hline 7 & School organization and management & 0.154 & & & & \\
\hline 8 & Availability of guidance & 0.500 & & & & \\
\hline 9 & Community involvement & 0.118 & & & & \\
\hline 10 & Community attitude & 0.283 & & & & \\
\hline 11 & Families home language & -0.115 & & & & \\
\hline 12 & Families educational level & 0.008 & & & & \\
\hline
\end{tabular}

Table 8. Hierarchical Multiple Regression Models summary

\begin{tabular}{|c|c|c|c|c|c|c|c|c|}
\hline \multirow{2}{*}{ Model } & \multirow{2}{*}{$\mathrm{R}$} & \multirow{2}{*}{$\begin{array}{l}\mathrm{R} \\
\text { square }\end{array}$} & \multirow{2}{*}{ Adjusted R-Square } & \multicolumn{5}{|c|}{ Change statistics } \\
\hline & & & & R-Square & F-change & $\mathrm{Df}_{1}$ & $\mathrm{Df}_{2}$ & Sig. \\
\hline 1(3) & 0.166 & 0.028 & 0.027 & 0.028 & 0.370 & 3 & 39 & 0.035 \\
\hline $2(7)$ & 0.416 & 0.173 & 0.167 & 0.173 & 1.044 & 7 & 35 & 0.049 \\
\hline $3(19)$ & 0.861 & 0.742 & 0.728 & 0.742 & 3.474 & 19 & 23 & 0.003 \\
\hline
\end{tabular}

\section{CONCLUSION}

The academic performance of the student depends on a number of socio-economic factors, teacher related variables, and student related variables only 19 of which have been identified by the researcher. This can explain at least $74.2 \%$ of proposed model. There may be other factors which may have direct effect on the performance of the students.

The mean score of the students result 54.05. The 55 median score is greater than the mean score of the students indicates that students who scored 55 and above grade point average are greater than $50 \%$ of the 
sampled students. There are 19 independent variables assumed to influence their academic performance. Teachers' educational level, teaching experience and subject matter knowledge have showed significant influence with the students' academic performance. Keeping all the other factors constant, $14.8 \%$ of the observed variation in the students' academic performance was due to differences in teachers' educational level, teaching experience and teachers' subject matter knowledge.

The regression analysis result indicated that $62.7 \%$ of the observed variation in the students' academic performance was due to different school level variables. Among student related variables, their interest towards education showed positive significant relationship with the students' academic performance whereas absenteeism from school portrayed negative relationship with the students' academic performance. Among the school structure and organization variables, distance of the school from student residency, teacher student ratio, students family income to supply the necessary materials for their children and availability of different materials such as text book for students and text book and teachers guide for teachers and availability of pedagogical center, library, laboratory were found to have positive relationship with the students' academic performance. In addition to school organization and management variables' other variables which has positive significant relationship were educational level of directors and supervisors.

Finally, availability of school guidance and counseling service, students' family educational level, their home language, families' involvement to solve educational problem and their home language, families' involvement to solve educational problem and their attitude towards teachers, a students in particular and for education in general portrayed positive significant relationship with academic performance of students. In general, this study found that teachers education level, experience, subject matter knowledge, students interest towards education, attendance of students, parents educational level, parents income, distance of the school from students' home, availability of guidance and counseling service, availability of the necessary educational materials in the school can make a different about the students' academic performance.

\section{REFERENCES}

[1] Brookover, W.B. \& Lezotte, L.W., Changes in School Characteristics Coincident with Changes in Student Achievement. East Lansing, MI: Michigan State University, 1979.

[2] Carrotte, P., Turning academics into teachers. In S. Rowland et al. Teaching in Higher Education, 4(3), 411-414, 1999.

[3] Chaudhry, A.H., Effect of Guidance Services on Study Attitudes, Study Habits and Academic Achievement of Secondary School Students. Bulletin of Education \& Research 28, (1), 35-45, 2006.

[4] Creemers P. M., From school effectiveness and school improvement to effective improvement. Research and Evaluation, 8:343-362, 2002.

[5] Endawke, et al., Quality of Higher Education in Ethiopian Public Institutions. Forum for Social Studies. Addis Ababa University Press, 2009.

[6] Henderson, A. T. and Berla, N., A New Generation of Evidence: The Family is Critical to Student Achievement. Washington DC: National Committee for Citizens in Education, 2004.

[7] Linnakyl, P., Malin, A. and Taube, K., Factors behind low reading literacy achievement, 2004.

[8] Negash, T., Education in Ethiopia: From crisis to the brink of collapse. Nordiska Afrikainstitutet-33. Uppsala, Sweden: Nordiska Afrikainstitute, 2006.

[9] Raychaudhuri, Amitava, Debnath, Manojit, Sen, Seswata \& Majundra, braja Gopal., Factors affecting Student's academic performance: A case study in agartala municipal concial area. Bangladesh e-journal of sociology, vol.7, No. 2, 2010.

[10] Saeed, K. A., Quality in higher education and universities. Paper presented at National Conference on Quality Assurance in Education in Pakistan. Pakistan Institute of Quality Control Lahore [11], 2003.

[11] Teferra, D., Building research capacity in Ethiopian universities: The realities and the challenges. Speech on United Nations Economic Commission for Africa (UNECA). Retrieved from: http://www2.bc.edu/\%7Eteferra/Building_Research_Capacity_in_Ethiopia.html, 2007.

[12] UNESCO, Report on the development of education in Ethiopia to the UNESCO forty-seven session of the international conference on education. Geneva, Switzerland. Retrieved from: http://www.ibe.unesco.org/International/ICE47/English/Natreps/reports/ethiopia_scan.pdf, 2004.

[13] Wagaw, Teshome G., 'African Higher Education in Collaboration to Respond to Contemporary Development Imperatives', Equity \& Excellence in Education, 34: 3, 54 - 55, 2001.

[14] Wankowski, J., Success and failure at university, in: K. Raahein, J. Wankowski and Redford. (1991).Helping Students to Learn: teaching, counseling, research, pp. 259-267, London, society for research into Higher Education and OUP, 1991.

[15] World Bank, Education in Ethiopia: Strengthening the foundation for sustainable progress. Washington, DC: The World Bank, 2005.

[16] Yamane, Taro, Statistics, an Introductory Analysis, 2nd Ed., New York: Harper and Row, 1967. 